\title{
停留䁄丸の内分泌学的研究
}

\author{
第 2 報 思春期前後の停留坥丸症例における
}

androgen biosynthesis (in vitro) の検討

横浜市立大学医学部泌尿器科学教室 公 平 昭 男
(主任:高开修道教授)

\section{ENDOCRINOLOGICAL STUDIES ON CRYPTORCHIDISM}

Part 2. Reference of Androgens Biosynthesis of Testes, Especially in

Human Cryptorchidism.

Teruo Kohdaira

Department of Urology, Yokohama City University School of Medicine, Yokohama, Japan

(Director: Prof. Dr. Shudo Takai)

In the first report the author stated that androgens biosynthesis of various testicular tissues could be compared each other by using $30 \mathrm{mg}$ testicular biopsy speciemen.

This article is based on the result of androgens biosynthesis on human cryptorchidism. Summaries are as follows:

1. The ability of undescended testes to convert progesterone- $7 \alpha-{ }^{8} \mathrm{H}$ to $17 \alpha$-hydroxyprogesterone, 4 -androstenedione and testosterone was compared with that of contralateral intrascrotal testes.

It was noted that the testosterone conversion rate of cryptorchid testes in under 4, 5-10, 11-13 and adult age group were $0.66 \pm 0.48 \%(\mathrm{~N}=4), 1.15 \pm 1.20 \%(\mathrm{~N}=8), 6.44 \pm 3.18 \%(\mathrm{~N}=3)$ and $7.9 \pm 2.2 \%$ $(\mathrm{N}=3)$, respectively. On the other hand, the conversion rate of the contralateral intrascrotal testes in the above mentioned age groups were $0.43 \pm 0.02 \%(\mathrm{~N}=2), 5.05 \pm 3.73 \%(\mathrm{~N}=5), 17.00 \pm 0.00 \%(\mathrm{~N}=1)$ and $19.30 \pm 0.00 \%(\mathrm{~N}=1)$, respectively.

It was clearly demonstrated that the great difference of conversion rate began at the age of 5 .

2. During the prepubertal ages, it was strongly suggested that the normal subjects was higher than that of contralateral intrascrotal testes of cryptorchid patients.

3. From the results mentioned above it was proved that testicular interstitial function at prepubertal stage was not silent, but actually active.

4. Nowadays, it is generally supported that spermatogenesis depends upon androgen concentration in testicular tissue and FSH does not play a main role in spermatogenesis.

It was suggested that the decrease of testosterone formation in testicular tissue could be a main cause of infertility of the patients with undescended testes.

\section{はじめに}

すでに第 1 報で述べた如く，芧丸組織中の androgen 生合成能の検索に打いて検体組織の微量化に成功し, そ の結果辠丸生検組織 を使用し androgen 生合成能の in vitro に打ける追跡が可能であると報告した ${ }^{11}$. 従来, ヒ 卜停留睪丸の間質細胞機能は正常であると考兄られてい たが，このたび本実験法を適応し間質細胞機能を検討し
た結果，興味ある知見をえたので報告する．

\section{対}

対象は 2 歳より 25 歳までの片側性停留搻丸症例におい て停留側闰丸 18 , 反対側陰辜内闺丸 9 , 正常とみなした

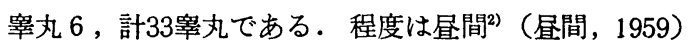
の分類によれば全例 II 〜 II 度である．これらの症例はす べて今回治療をらけるまで他医でホルモン剤の投与及び 
表 1 Materials

\begin{tabular}{c|c|c|c}
\hline Age & $\begin{array}{l}\text { Undescended } \\
\text { testes }\end{array}$ & $\begin{array}{c}\text { Contralateral } \\
\text { intrascotal. T. }\end{array}$ & Normal T. \\
\hline $2 \mathrm{~W}$ & & & 1 \\
\hline $2 \mathrm{Y}$ & 1 & & 2 \\
\hline 3 & & & \\
\hline 4 & 3 & 1 & 1 \\
\hline 5 & 1 & 1 & 1 \\
\hline 6 & 2 & 1 & \\
\hline 7 & 1 & 1 & \\
\hline 8 & 2 & 1 & \\
\hline 9 & 1 & & \\
\hline 10 & 1 & & \\
\hline 11 & 1 & & \\
\hline 12 & 1 & & \\
\hline 13 & 1 & 1 & \\
\hline 21 & 1 & & \\
\hline 22 & 1 & & \\
\hline 23 & 1 & & \\
\hline 25 & 18 & & \\
\hline Total & & & \\
\hline & & & \\
\hline
\end{tabular}

手術的治療をらけていないものである。また他に明らか な身体異常, 例えば脳性麻痺, 脊椎破裂, 尿道下裂, 鎖 肛, Prader-Willi 症候群その他の奇形症候群及び染色体 異常を合併せず，かつ成人例においては二次性徵の正常 とみられる単純性ともいうべき停留辠丸症例である。 た術前に最底 5 回以上触診の機会を有し移動性辠丸を除

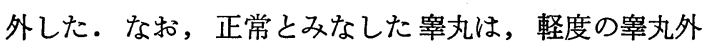
傷, 及び陰囊水腫などの比較的正常に近いと思われる辠 丸組織を採取し対照とした（表 1 ).

\section{測 定 法}

悬丸固定術時, 採取する辠丸組織は $30 \mathrm{mg}$ に統一し, $-20^{\circ} \mathrm{C}$ に冷凍保存した。基質は, progesterone- $7 \alpha-{ }^{3} \mathrm{H}$ $(9.6 \mathrm{mCi} / \mathrm{mM}) 1.0 \mu \mathrm{Ci}$, incubation 時間60分の条件下で pogesterone (Prog) より testostrone (T.) までの steroid 変換生成率を検索した。

測定法の詳細は，第 1 報1)に記載したので省略する・

\section{結 果}

結果は, 基質である Prog.より最終産物である T. に いたる各生成物への変換率で表現し，T，の生成変換率
図 1 The Metabolic Pathway of Androgens in Testis

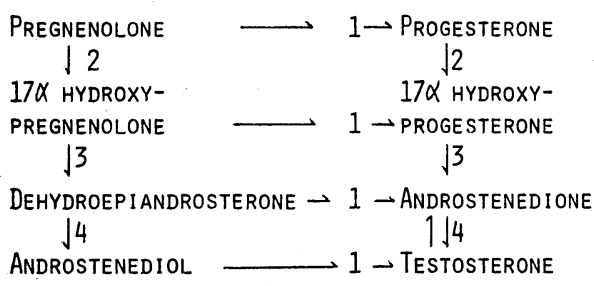

$1 \quad \triangle 5-3 \beta$-HYDROXYSTEROIDDEHYDROGENASE

$2 \quad 17 \alpha$-HYDROXYLASE

$3 \quad c_{17}-c_{20}$ LYASE

$4 \quad 17 \alpha$-HYDROXYSTEROIDDEHYDROGENASE

をもつて基質より T. までの経路の酵素活性の総括的評 価とみなした（図 1 ).

停留側睾丸及び反対側陰囊内冝丸に括ける各生成物の 変換率は表 2,3 のとうりである.

これから各年龄群別に T. 生成率をみると, 0 〜歳

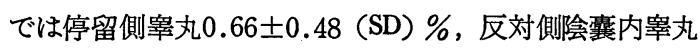
$0.43 \pm 0.02$ (SD) \% と共に $1 \%$ 以下で本実験法より解釈 すると T. の生成はみられず従つて停留側辠丸と反対側 陰慗内䁄丸の T. 生合成能に差を有していないとみてよ W.

5〜10歳では，停留側鼻丸では1.15土1.20 (SD) \%， 反対側陰囊内辠丸では5.05土3.75 (SD) \% と停留側粹丸

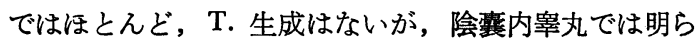
かな T. 生成の上昇がみられた. 11〜13歳では, 停留側

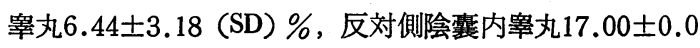
(SD) \% , 双方共 $\mathrm{T}$. 生成は急速に増加する. 成人例

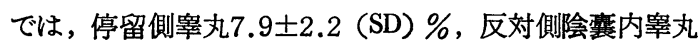
は, $19.30 \pm 0.0$ (SD) \%で成人に至つても停留側鼻丸は 依然として陰囊内粹丸に比べ T. 生成は低下している (表 $2,3,4$, 図 2).

さて, 本論文で扱う正常例とは先にのべたごとく軽度 陰囊水腫症例, 辠丸奇形腫における反対側辠丸など全く 正常とはいいがたい睪丸であるが，しかしながら停留側 辠丸及びその他の病的童丸と比較した場合にはこの正常 とみなした睾丸はより真の正常辠丸に近い機能であろう と解釈して, 軽度陰襄水腫症例及び睾丸奇形腫の反対側 辠丸などを停留殬丸に括ける $\mathrm{T}$. 生合成能の検索の対照 とみなした。 


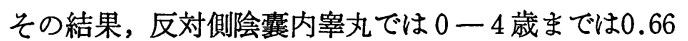
\pm 0.48 (SD) \%であり，5歳3.43\%，6歳1.87\%，7歳 $5.43 \%, 8$ 歳 $2.43 \%$ と, 5 歳より 8 歳の間において T. 生成能は存在するがその生合成率は低く9歳にいたつて はじめて $12.1 \%$ 一昇がみられた。一方, 正常例では, 5 歳では反対側陰囊内と同様に $2.6 \%$ 低いが， 6 歳で
はすでに，13.6\%に上昇がみられた。

正常例の生後 2 週及び 2 歳の 2 例共, それぞれ, 18.4 \% , 18.6\%と著明な T. 生成の増加がみられた。これに ついては，反対側陰囊内萳丸に対応すべき症例がないの で比較はさしひかえたいが，いずれにしても反対側陰襄 内粹丸に和ける T. 生成は正常例と比較して T. 生成の

表 2 Androgens Formation From Progesterone in Undescended Testes

\begin{tabular}{c|c|c|c|c|c|c}
\hline Age & Progesterone & 17 - PRO & A' dione & Testosterone & 16 - PRO & 20 - DHP \\
\hline 2 & 56.3 & 1.72 & 0.83 & 1.32 & - & 0.44 \\
\hline 4 & 59.3 & 0.18 & 7.30 & 0.12 & - & 0.31 \\
\hline & 58.7 & 0.17 & 6.22 & 0.29 & 1.32 & 1.58 \\
\hline 5 & 45.4 & 0.45 & 6.73 & 0.96 & 0.88 & 2.32 \\
\hline 6 & 59.6 & 0.22 & 6.20 & 0.40 & 0.49 & 0.88 \\
\hline & 61.3 & 0.22 & 5.32 & 0.73 & 1.01 & 2.01 \\
\hline 7 & 41.8 & 1.94 & 4.43 & 2.89 & 1.60 & 4.51 \\
\hline 8 & 41.5 & 0.18 & 6.68 & 0.22 & 1.32 & 0.44 \\
\hline & 43.7 & 0.30 & 7.02 & 0.53 & 1.60 & - \\
\hline 9 & 27.0 & 10.10 & 3.02 & 3.50 & 21.6 & - \\
\hline 10 & 56.9 & 0.21 & 7.34 & 0.36 & 0.53 & 1.35 \\
\hline 11 & 46.5 & 7.50 & 1.87 & 6.51 & 3.21 & 1.56 \\
\hline 12 & 54.7 & 2.73 & 3.92 & 2.50 & - & 1.81 \\
\hline 13 & 6.3 & 15.3 & 2.86 & 10.3 & 34.6 & - \\
\hline 21 & 4.59 & 9.42 & 4.62 & 10.3 & - & 17.3 \\
\hline 22 & 11.3 & 15.8 & 8.65 & 4.9 & 14.2 & 0.0 \\
\hline 23 & 1.64 & 14.8 & 7.44 & 8.35 & - & 24.4 \\
\hline
\end{tabular}

(Percent of conversion)

表 3 Androgens Formation from Progesterone in Contralateral Intrascrotal Testes

\begin{tabular}{c|c|c|c|c|c|c}
\hline Age & Progesterone & $17-$ PRO & A' dione & Testosterone & 16-PRO & 20-DHP \\
\hline 4 & 59.8 & 0.20 & 5.80 & 0.41 & 0.98 & 1.78 \\
\hline & 53.7 & 0.20 & 6.01 & 0.45 & 0.62 & 0.69 \\
\hline 5 & 63.6 & 0.25 & 6.36 & 3.43 & 1.67 & 1.49 \\
\hline 6 & 40.9 & 4.86 & 0.60 & 1.87 & - & 7.57 \\
\hline 7 & 43.9 & 3.89 & 2.43 & 5.43 & 2.91 & 5.62 \\
\hline 8 & 42.8 & 3.10 & 3.72 & 2.43 & 3.00 & 0.0 \\
\hline 9 & 9.82 & 20.1 & 2.31 & 12.1 & 8.9 & 0.0 \\
\hline 13 & 3.80 & 10.6 & 2.14 & 17.0 & 32.1 & 0.0 \\
\hline 22 & 6.30 & 6.8 & 1.53 & 19.3 & 40.3 & 0.0 \\
\hline
\end{tabular}

(Percent of conversion) 
表 4 Testosterone Formation in Cryptorchidism

\begin{tabular}{c|c|c}
\hline Age & Undescended testes & Intrascrotal testes \\
\hline $0-4 \mathrm{y}$ & $0.66 \pm 0.48 \%(\mathrm{~N}=4)$ & $0.43 \pm 0.02 \%(\mathrm{~N}=2)$ \\
\hline $5-10$ & $1.15 \pm 1.20 \%(\mathrm{~N}=8)$ & $5.05 \pm 3.73 \%(\mathrm{~N}=2)$ \\
\hline$(0-10)$ & $0.99 \pm 1.04 \%(\mathrm{~N}=12)$ & $3.73 \pm 3.78 \%(\mathrm{~N}=7)$ \\
\hline $11-13$ & $6.44 \pm 3.18 \%(\mathrm{~N}=3)$ & $17.00 \pm 0.00 \%(\mathrm{~N}=1)$ \\
\hline Adult & $7.9 \pm 2.2 \%(\mathrm{~N}=3)$ & $19.30 \pm 0.00 \%(\mathrm{~N}=1)$ \\
\hline
\end{tabular}

(\% of conversion)

低下が存在する事が強く推測された（表 5 ).

\section{考按}

（1）現在に打惊停留蛙丸の考方方

停留辠丸は泌尿器科領域に颃いて頻度の高い疾患の 1 つである事は今さらいうまでもない，そのため多くの研 究者による様々の業績がみられる.

ここで現在の本症に対する考方方, 治療の問題点につ いてのべてみたい．現在まで主として次の 3 点について 研究がなされている.

a) 本症の精細管に和ける变化（精細胞の分化遅延, 精細管の硝子化, 線維化, 基底膜の肥厚など）を中心と した病理組織学的研究では多くの報告がみられる。

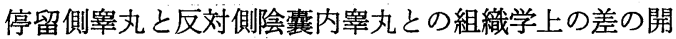
始時期としては，すでに 2 歳 (Cooper, 1929) ${ }^{3)}$ ，あるい は3 歳(Hecker et al, 1967) 告から 6, 7 歳 (Nelson, 1951) ${ }^{5}$, (Robinson et Engle, 1954) $)^{6)}$ (Hinman, 1955) $)^{7)} 10$ 歳 (Sniffen, 1952) $)^{8)}$,

(Hand, 1957)9), (Schwartz et al, 1956) ${ }^{10)}$ ，あるい は思春期まで差を認めないとする報告（Wangensteen， $1927)^{11)}$ ，(Rea，1942) ${ }^{12)}$ まで様々である。

ここで注意するべき事は，この開始年龄は反対側陰霊 内睾丸との比較からの結果であり正常等丸との比較では ない. 従つて, この両者間の差を生ずる時期までの停留
図2 Testosterone Formation in Cryptorchidism

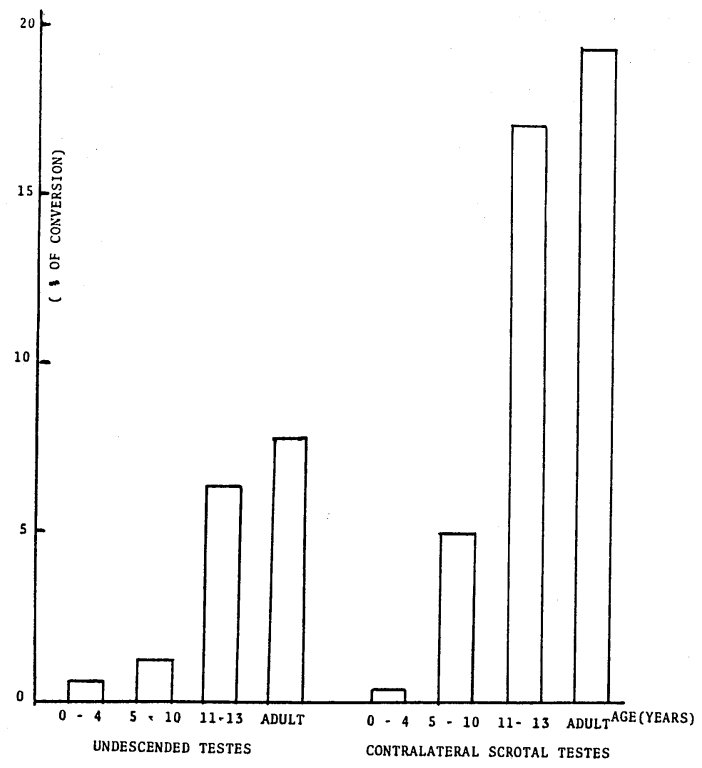

側舎丸がはたして正常に発育したかどうか問題である。 つまり停留側と反対側陰䫔内粹丸の精細管に 組織学的 上の差が生ずる以前は正常とみなしてょいかという問題 がある。

b ）停留側鼻丸の变化を最少限の状態に拈さえるため には辠丸固定術を何歳に適応すべきかが最大の問題であ り一般には, 自然下降の頻度が低下し下降の頻度が固定 化する 3 歳から, 組織学的に反対側陰囊内蟠丸との間に 精細管所見上に差が生じはじめるという5 歳の間に手術 をするべきであるという考方方が有力(大田黒，1968) $)^{13)}$ であるが，この手術時期の決定については現在な和多く の問題点が残されている.しかしながら，現時点では判 断すべき基準がこれ以上存在しないためともい方る.

この考方方は停留側辠丸そのものが直接妊孕力の低下

表 5 Androgens Formation in Normal Cases

\begin{tabular}{|c|c|c|c|c|c|c|}
\hline & PROG. & 17 PROG. & A' ndro & Testosterone & 20-DHP & 16-P \\
\hline $2 \mathrm{~W}$ & 9.32 & 28.7 & 8.92 & 18.4 & 2.23 & \\
\hline $2 \mathrm{yrs}$ & 7.30 & 23.9 & 8.9 & 18.6 & 19.8 & \\
\hline 5 & 39.7 & 1.6 & 27.0 & 2.6 & 1.0 & \\
\hline 6 & 8.29 & 30.3 & 0.51 & 13.6 & 14.3 & \\
\hline 12 & 1.32 & 24.8 & 9.64 & 12.8 & 5.50 & \\
\hline 25 & 6.15 & 22.2 & 11.4 & 19.1 & & \\
\hline
\end{tabular}


に関与するといら考方方にたつている，実際には，片側 性停留辠丸症例の精液所見すなわち, 妊孕力の可能性は

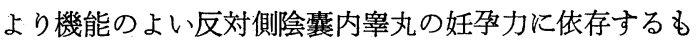
ので, 停留側辠丸の精子形成能々れ自身を直接反映して いるとは思觉ない。

さらに，一定の時期に蛙丸固定術を施行した場合とそ らでない場合の殬丸組織学上の差異について現在十分納 得できるだけの結果はでていない。

そして，片側性停留辠丸症例に括いても50～60\%は不 妊であるといら事実は (後述), 反対側陰囊内㝢丸の精子 形成能をも再検討を要する問題である.

c) human Chorionic Goradtropin (h.C.G.) と蟠丸下 降及び 造精機能に関する研究は本邦に沶いても和久 ${ }^{14)}$

（和久，1957）らにより報告されている.

睪丸下降については，妊婦尿よりの抽出物質が猿の莘 丸下降に効果があるといら1932年の Engle ${ }^{15)}$ の論文に根 拠を求め, その臨床的有効性から h.C.G. の投与が施行 されてきている. しかし h.C.G. 投与によるヒ卜停留粹 丸の下降については, 評価はまちまちであり, また精子 形成促進については悲観的な報告が大部分である.むし ろ大量の h.C.G. 投与により精細胞分化の抑制作用がお こるといら意見もみられる (Charny, 1960) ${ }^{16)}$.

近年, 精子形成能と辠丸間質細胞機能とが極めて密接 な関連を有している事が明らかにされつつあるが，本症 に打いても従来のごとく単に精子形成能の探求にとどま らず, 内分泌学的側面, すなわち辠丸間質細胞機能の解 明がなされなければならない。

このように, いまだ本症の病態, 治療について確立さ れた見解はなく現在行き詰つた状態にあるといつて過言 ではない。

（2）停留辡丸に打ける間質細胞機能研究の変遷

本症の間質細胞は, 病理学的に正常と思われ, 二次性 徵も正常である事から従来本症は, 内分泌学的には異常 は存在しないとされてきた(Wilkins，1955) ${ }^{17) ，(D a n i e l, ~}$ 1969) ${ }^{18)}$, (Williams, 1974) ${ }^{19)}$.

しかし内分泌学的に異常を指摘している報告も少数散 見される.1934年, Nelson ${ }^{20)}$ は, ラットを用いて実験的 に停留化させた結果, 精襄腺重量の減少をみたとのべて いる. 1937年, Hanes ${ }^{21)}$ は, cryptorchid pigを用い bioassay により androgen が正常より50\%も減少している とのべている. 1949年, Engberg22) は, 同様に bioassay によりヒトの停留箤丸症例では正常例と去勢例の中間の 值を示すとのべている. しかし，これらは bioassay で
あり正しく評価されているかはなはだ疑問である。

尿中 17-oxosteroid が，1940１950年代から測定可能 になり多数測定されるようになつたが本症に打いては， 17-oxosteroid 值は正常であり, 成人例でかつ両側性の 症例で時に減少がみられるといら程度であつた.17-oxosteroid は，2/3が副腎由来でありこれも正しい機能を反 映しているとはいえない。

一方, 組織化学的には Mancini ${ }^{22)}$ (1965) は cytochrome oxidase, succinic dehydrogenase 及び leucyl aminopeptidase について検討しているが，本症の間質細胞に ついては正常との間に差を見出していない。Baillie ${ }^{23)}$ (1966) は, $\Delta^{5}$-3 $\beta$-hydroxysteroid dehydrogenase につい て検討し，13歳以上の本症では正常と同じ pattern を示 すとのべているまた落合ら ${ }^{24)}(1965)$ 及び, Sengoku ${ }^{25)}$ （1967）は小児期では LDH，DPN-P の活性が認められ ALP，ACP は陰性であつたという。 また思春期後の間 質細胞の酵素活性は良好で陰製内睪丸と变化ないとのべ ている. 組織化学的变化の判定は多分に主観的な要素が 入ると思われるが, 要するに従来の報告は正常と比較し 大きな変化を認めていない。

電顕学的には，1966年 Roland ${ }^{26)}$ は10-12歳では反対 側陰製内辠丸には滑面小胞体に富む Leydig 細胞が存在 するのに対し停留側睾丸にはわずかしか存在しないとの べている. 1973年 Hadziselimoric ${ }^{27)}$ は，本症の間質に は, 2 歳から collagen fiber が多数存在するとのべて いる. また近藤 ${ }^{28)}$ (1962) も，電顕学的に間質の collagen fiber の出現をみとめているが，電顕学的に間質細 胞に言及した論文は少い. 更に本症については電顕学的 研究は少い。

1960年代より radioisotope を用いた測定法の進歩に より内分泌学に和いても発展がみられた。その1つは competive protein bindingassay (C.P.B)である. C.P.B. を用いての血中 T. の測定が開始された（Frasier, 1969) ${ }^{29)}$, (Wieland, 1970) ${ }^{30)}$, (丹田, 1971) ${ }^{31)}$. (穂坂ら, $1972)^{32)}$.

しかし C.P.B. に打いては従来の方法に比較しはるか にその特異性, 精度に拈いてまさつたものの小児, 婦人 の血中 $\mathrm{T}$. 值 $50 \mathrm{ng} / \mathrm{dl}$ 以下の精度については問題があつ た.

1970年になつて radioimmunoassay (R.I.A) の進歩に よりさらに精度のよい血中 T. が測定されるようになつ

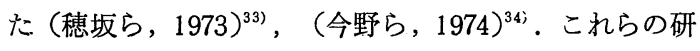
究手段は, 畕丸間質細胞機能を解明するためには必須の 
ものであるが, 先にのべたごとくその手段の進歩は極く 近年のことであり停留辠丸症例に適応された報告はいま だ散見する程度である (Canlorbe et al，1974) ${ }^{35}$.

著者は，この R.I.A. により本症の血中 T. を測定し ているが，その測定結果については次報でのべる予定で ある。

一方，1956年 Slaunwhite ら ${ }^{71}$ 及び Axelrod ${ }^{72)}$ (1965) をはじめとして追跡実験法による in vitro に拈ける androgen 生合成能の検索が可能となつた。本実験法は radioisotope により label された基質を睾丸組織の homogenate と incubation する事により殬丸組織中の steroid 生成経路に関与する酵素の存在下で基質より各生 成物である steroid への生成変換をはかり，さらにその 生成変換された代謝物の radioactivity を測定する事に より辡丸組織中の代謝産物の種類及びその間に関与する 酵素の活性を知る方法である. 本実験法により停留辠丸 症例に扣ける間質細胞機能を知るため第 1 報では本実験 法における検体組織の微量化の実用化に成功した ${ }^{11}$ 。本 実験法の詳細については第 1 報を参照されたい。

次に停留南丸に括ける in vitro の androgen 生合成能 の検索の変遷についてのべる.

1961年 Huseby ら ${ }^{36)}$ は，マウスを用いて実験を招こ ない $\Delta^{4}$-androstenedione $\left(\Delta^{4}-\mathrm{A}^{\prime}\right.$ dione $)$ より T. への変 換率は正常辠丸とほぼ同等であるとした．1967年 OnoImai ${ }^{37)}$ は，ラットを用いて検討し17 $\alpha$-hydroxylation, Side-chain splitting activity 及び $17 \alpha$-hydrogenation は 正常峝丸と大差ないと報告している. 1968年 Inano ら ${ }^{38)}$ は，ラットを用いた実験で $\Delta^{5}$-3 $\beta$-hydroxysteroid dehydrogenase activity は正常の $40 \%$ に減少しているが, $17 \beta$ -

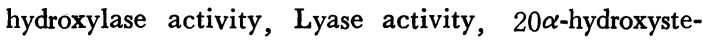
roid dehydrogenase activity 及び $17 \beta$-hydroxysteroid dehydrogenase activity は，むしろ增加しているとのべて いる.

一方，1973年 $\mathrm{Abraham}^{39)}$ はラットの先天性遺伝性停 留奠丸症例を用いて T. の生合成能を検討し停留側辠丸 では反対側陰㹕内殬丸より低下が認められたという。

今までのべてきたように従来，本症の間質細胞機能に ついては種々の実験法により研究されてきたが，その結 果はほとんど正常であると結論されている.

また，実験的停留辡丸に拈いても，その steroid 生合 成能への影響は比較的少いといら報告が大部分のようで ある. しか子実験的停留辠丸についての結果は, 一且, 陰營内に下降した正常等丸を手術的に腹部に停留化させ
たための変化であり, 先天的に停留化しているヒト停留 圅丸と同列に扱ら事は出来ない。

その点, Abraham の報告はラットではあるが先天性 遺伝性の停留辠丸症例であり，よりヒトの場合に近いと 思われる。この結果では停留側鋅丸に，T．の生成低下 が認められ自験例の結果と一致するものである.

（3） 七卜停留鼻丸症例に拈ける androgen 生合成 先にのべたごとく動物においては報告が比較的多くみ られるが，実際にヒト停留睾丸について検索した報告 は少い. 1962片山 ${ }^{40)}$ は，Prog. を基質として少数例に検 討を拈こない生成物の減少を認めたとのべている.1969 年 Hamilton ${ }^{41)}$ は, $5 \sim 13$ 歳の 6 例の七卜停留辠丸症例 について 検討し $3 \beta$-hydroxysteroid dehyorogenase の活 性が減少する傾向にあるとのべ，これは胎生12〜16カ 月の胎児辠丸と同様の傾向でありこの interstitial cell deficit が停留する原因となるのではないかとのべてい る。また1973年吉田，大島 ${ }^{42)}$ は，思春期後の 3 例の停 留辠丸について ${ }^{14} \mathrm{C}$-pregnenolone 及び ${ }^{14} \mathrm{C}-17 \alpha-\mathrm{OH}-\mathrm{P}$, を，基質として実験を和こない全例に拈いて $17 \alpha$-hydroxylase, $3 \beta$-hydroxysteroid dehydrogenase の活性低下及 び T. 生成の減少を認めたと報告した.

この様にヒト停留辠丸については少数例について散見 するにすぎないが，いずれも steroid 生成低下を認めて いる.

自験例においては，第 1 報で報告したごとく生検組織 での検索が可能となつたため年齢的変化について，また 反対側陰囊内辠丸についての検索も可能となつた。その 結果, $0 \sim 4$ 歳に怙いては停留側章丸，反対側陰襄内辠 丸共に $1 \%$ 以下の $\mathrm{T}$. 生成率であり差は認められない。

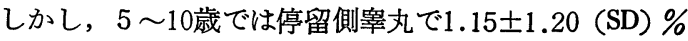
, 反対側陰囊内辠丸では， $5.05 \pm 3.73$ (SD) \%と 5 歳を 境界として両者間に T. 生成の差を生じた，また11〜13 歳に至ると10歳以下に比較し急速に T. 生成は増加し

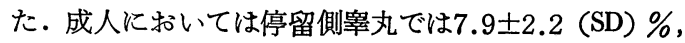
反対側陰襄内辠丸では $19.30 \pm 0.00$ (SD) \%で明らかに 停留側囯丸の T. 生成は低下が見られた。また正常例之 の間にも差の存在する事が強く推測された。

片山の実験については基質は自験例と同じ Prog. で あるが，生成物についての詳細は明らかでない，HamiIton は自験例では検索しえない $3 \beta$-hydroxysteroid dehydrogenase についてしらべ停留輧丸に执いてこの酵素 活性が減少傾向にあるとしている．しかし Hamilton の 主張しているごとくこの酵素の減少が胎児辠丸にも同様 
に認められることから直ちに停留化する原因であるとす るのは疑問である. 一方, 吉田, 大島の報告は 3 例では あるが Pregnenolone，及び $17 \alpha$-OH-P の両者を基質と して $17 \alpha$-hydroxylase, $3 \beta$-hydroxysteroid dehydrogenase の低下及び T. 生成の減少をみている. 自験例において は生検組織を用いるため最終産物である T. 生成率をむ つて全経路の酵素活性の評価とみなしているわけである が, 自験例の結果ばかりでなく他の報告からも, 停留幸 丸に打ける storoid 生成能は低下している事は, 明らか となつた。

（4）思春期前の冝丸間質細胞機能

尿中 17-oxosteroid 值さらには, 血中值 T. の測定結 果から従来より10歳以下の思春期前の辠丸は androgen を生成分泌していず内分泌学的には静止状態にあり, 11 〜13歳頃より Leydig 細胞として急速に活動を開始する ものと思われてきた。

ところが, 自験例に和いては 5 10歳に打いて T. 生

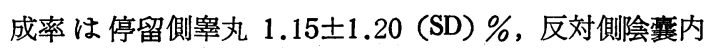

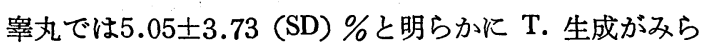
れ，かつ両者の間に差が認められた. この事実は steroid 生成に関与する酵素が active である事を示し; 基質が 与えられる事によつて変換生成が括こなわれる事を示し ている.玉置 ${ }^{43)}$ (1973) によれば，ホルモンの生成には 細胞自体の構造は必要なるのではなくその生合成は細胞 を構成している成分により扣こなわれる可能性をのべて いる.すなわち必ずしも Leydig 細胞に成熟していなく ても steroid 生成が存在する可能性をのべている.

Folman $^{45)}$ (1973) は幼若ラットの辠丸では間質細胞 に $5 \alpha$-reductase が存在し, 生成されたT.はこの酵素の 作用により dihydrotestosterone (D.H.T) をへて， $\Delta^{4}$-androstanediol に変換されてしまい, 成熟期では間質細胞 内の $5 \alpha$-reductase は減少し精細管に $5 \alpha$-reductase が増 加して T. を D.H.T. に変換するとのべている. 一方, 松本ら ${ }^{46)}$ (1972) は思春期前のラットで Prog, $17 \alpha-\mathrm{OH}$ $\mathrm{P}$ が $5 \alpha$-reductase の作用をらけて側鎖が切れ $5 \alpha$-reduced $\mathrm{C}_{19}$-steroid を生成する $5 \alpha$-reduced 経路を発見して いる.

また臨床面からは，Lee ら 47)（1974）は小児の停留 章丸症例の場合片側性であろうと両側性であろうと血中 LH のレベルは正常であり，もし上昇している場合には それは先天性醉丸無形成 anorchia と考えてょいと発表 した。また Penny ら ${ }^{48)}$ (1970), Jenner ら ${ }^{49)}$ (1972) 及 び岩動ら ${ }^{50)}$ (1972) も gonadal dysgenesis を有する小児
では同年龄の小児に比較し血中 gonadtropin のレベルは 上昇していると報告している.

これらの事実は，いずれる小児の悬丸は決して静止状 態にあるのではなく steroid 生合成能が存在し, それら が中枢へ働きかけをしている証拠を示するのである。こ の小児に括ける hypothalamus-pituitary-gonadal system については, Odell ら ${ }^{51)}$ (1971) によれば, hypothalamus の性ホルモンに対する感受性が成人と異なるという小児 特有の調節機構が存在する可能性をのべている.この思 春期前の調節機構については第 3 報で詳細に検討を加え る予定である.

いずれにしても自験例の結果から，in vitro に护ける 検索ではあるが10歳以下の思春期前の小児闰丸に接いて T. 生成能が存在する事が証明された。

（5） steroid 生合成に括ける年齢的变化

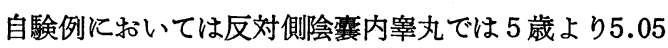
\pm 3.73 (SD) \%と T. 生成は上昇し, さらに11 13藏で

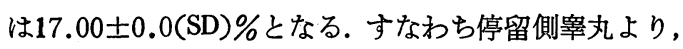

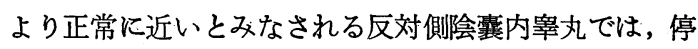
留側辠丸と同様に0〜4歳までは梳とんど T. 生成は認 められないが，5歳〜10歳の間で明らかに T. 生成が認 められている. また11〜13歳の間で $\mathrm{T}$. 生成の急速な増 加がみられた。一方, 血中 T. の年龄的变化と比較す

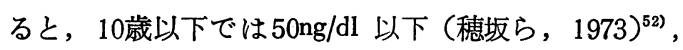
(今野ら，1974) 吕)であり，血中 T. のレベルのみからは 10歳以下に和ける間質細胞の活動は見出し得ない。しか し11〜13歳に怙ける血中 T. 值は T. 生成率と同様にこ の年齢層に打いて急上昇する.

少数例ながら正常に近いとみなした症例の T. 生成に ついてみると特に生後 2 週の舎丸成熟奇形腫の反対側辠 丸では $18.4 \% ， 2$ 歳の陰糞水腫症例では $18.6 \%$ と著明な T. 生成がみられた.

これらの事実から出生後に T. 生成のピークが存在 し, その後あるレベルに下降し, それから思春期のピー クに徐々に上昇するのではないかと推測される。一方, Maguelone ら ${ }^{54)}$ (1973) は, 生後70～90日の間に血中 T. は約200ng/dl のピークを持ち以後減少すると報告し ている. 出生直後にピークが存在する事は一致している ようであるが，思春期までの变化については，血中 T. では急上昇するのに対し T. 生成率では徐々に増加し思 春期にいたつてさらに上昇がみられるようである（表 3,5 , 図3).

ところで, 図3にもみられるように steroid 生合成の 
図 3 Schematic Presentation of Aging Studies on Plasma Testosterone Concentration and Testosterone Biosynthesis in Testis

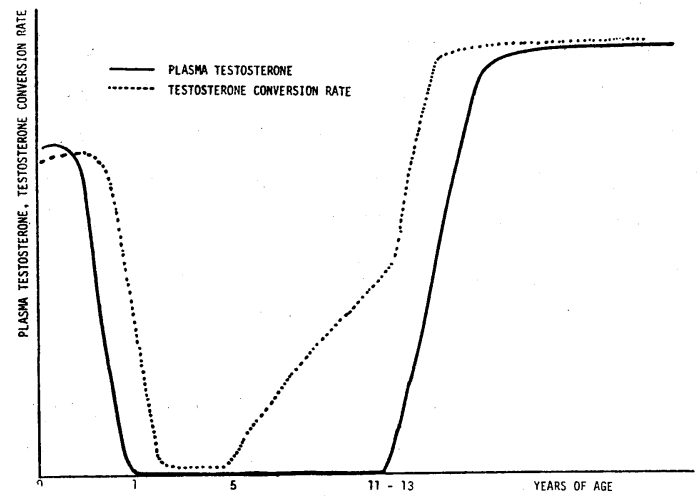

検索に拈いては 5 歳より $\mathrm{T}$. 生成の明らかな上昇が認め られたが，血中 T. に拉いては10歳以前には $50 \mathrm{ng} / \mathrm{dl}$ 以 下であり明らかな T. 分泌としては認められない.この 両者の差異については，2つの解釈がなされ.5る１つ は䓿丸内で，T. 生成がなされ実際に低いレベルではあ るが，血中に T. が分泌されているとする考え方，であ る.この場合, hypothalamus における androgen の receptor の感受性が高いため低いT. 值に対しても feed back 機構が作用する可能が考えられ．他の考え方は辠 丸内で T. 生成がなされるが，T. は直ちに D.H.T.よ $\eta$ androstanediol ${ }^{45)}{ }^{46)}$ 或は androsterone ${ }^{75)}$ (Inano et al, 1966）に変換され血中には T. は分泌されないとする考 え方である. 後者の場合でも androstanediol あるいは androsterone の biological action は T. と比較しそう低 下はみられず, (Liao et al, 1970) ${ }^{73)}$, (Vida, 1969) 十分 androgen として feed back 機構に作用する状態と 考兄れ, 先にのベた小巟にも存在する feed back 機 構と予盾しない。

（6） 反対側陰囊内辠丸に扣ける steroid 生合成

自験例に括いて停留側殬丸は反対側陰囊内辠丸に比較 し 5 歳より T. 生成が低下する事実が明らかとなつた。 さらに著者は反対側陰囊内睪丸と正常小児辠丸との $\mathrm{T}$. 生成を検討してみた。ここでいう正常小児辠丸というの は，正常とみなした辠丸であつて真に正常ではない事は 先にのべたごとくである. 反対側陰囊内睪丸では $0 \sim 4$ 歳では0.66士0.48 (SD) \%であり 5 歳 $3.43 \%, 6$ 歳 1.87 $\%, 7$ 歳 $5.43 \%, 8$ 歳 $2.43 \%$ と 5 歳より 8 歳までの $\mathrm{T}$. 生成は低く，9歳にいたつてはじめて $12.1 \%$ 上昇がみ られる。一方，正常例では 5 歳では $2.6 \%$ と低いが 6 歳
では $13.6 \%$ 上昇がみられた。これは反対側陰襄内殬丸 の 8 歳までの T. 生成率をはるかに越える T. 生成率で あり反対側陰囊内鋅丸では正常小児辠丸にくらべ T. 生 成の低下が存在すると思われた。

また生後 2 週及び 2 歳の 2 例はそれぞれ $18.4 \%, 18.6$ \%と著明な T. 生成の上昇がみられた。これは停留側堹 丸 2 歳の $1.72 \%$ の 10 倍以上の值であり，はるかに正常例 辠丸では T. 生成が上昇しているわけである.この事実 については反対側陰襄内辠丸に対応する年㱓の症例が得 られていないため反対側陰襄内睾丸と正常粹丸との比較 をする事は困難である。

（7）本症の治療方向

a) androgen と精子形成能

最近, ardrogen と精子形成能との関係が注目されて いる. Steinberger ${ }^{56)}$ (1971）によると精子形成に最も重 要な部分である減数分裂は androgen により完了すると のべている(図4).

図 4 Effect of Various Hormones on Spermatogenesis

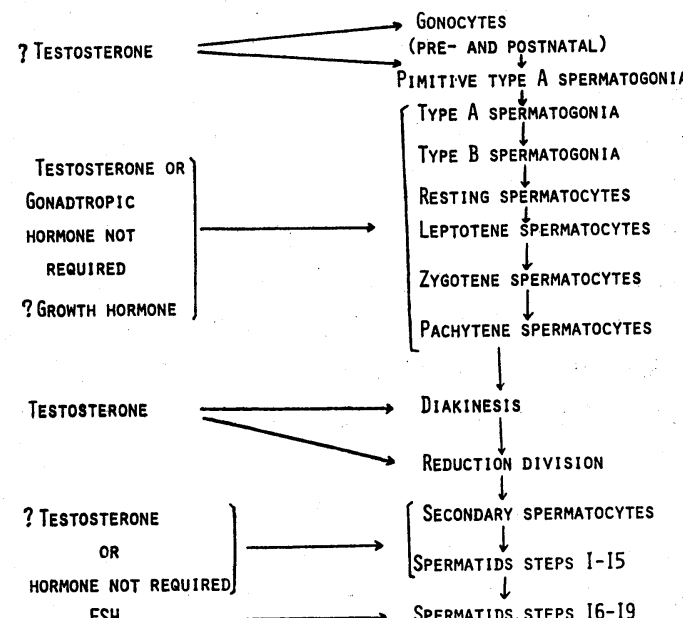

(Steinberger, 197I)

また Folman ${ }^{45)}$ は幼若ラットでは T. の活性型である D.H.T. が間質細胞で生成され直ちに排泄型である andro stanediol に変換されるのに対し成熟ラットでは精細管 での D. H. T. の生成が著明になるとのべている.

また Morse ${ }^{57)}$ (1973) は, 辠丸組織中の T. の減少と 共に精子数が極度に減少した実験結果から精子形成には 高濃度の T. が必要であることを示唆している.ささらに Gan Jamら ${ }^{58)}$ （1973）は副辠丸部精液中の T. 及び D. 
図 5 Androgen Transport and Receptor Mechanism

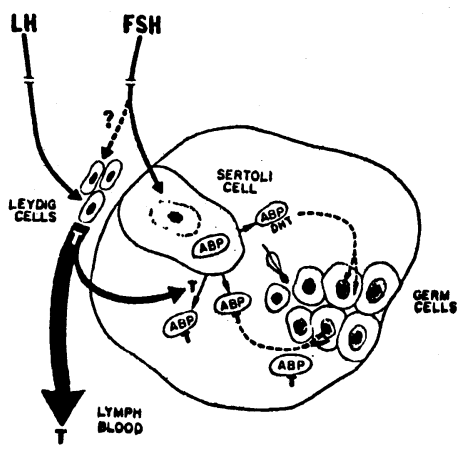

(HANSSON ET AL, , 1974)

H.T. が末梢血中より高いレベルにある事を確認し，こ れは精子の成熟に高濃度の androgen が必要なためであ るとしている。また Hansson ${ }^{59)}$ （1973）も Sertoli 細胞 に FSH が作用し androgen binding protein (A.B.P)を 增加させその T. が DHT に変換し精細管に括ける精子 形成を促進すると発表した（図 5 ).

これらの考方方は従来の FSH が精子形成の主役であ るといら考方方を否定し実は androgen が主役であり， しかも精子形成能の維持には闰丸内に高濃度の T. が必 要であることそそしてその濃度低下は直ちに精子形成低 下に結びつくことを物語るものである.

さて自験例の結果から，停留鋅丸においてはその間質

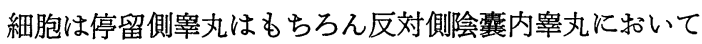
も機能低下が存在する事が強く推測された。停留莘丸は 本来 dysgenesis といわれ従つて本症の精子形成能の低 下は精細管自身の dysgenesis に基因するとも考兄られ るが，先にのべた事実からそればかりではなく間質細胞 機能低下る大きい要因を占めると考兄る必要がある.

Morse ${ }^{57)}$ とよれば，菳丸組織中の T. 濃度は末梢血中の 100倍にも及ぶとされ，一方穂坂ら ${ }^{60)}$ (1975) によれば 二次性徵発現に要求される末梢血中 T. はそれ和ど高い ものは必要ないだろうといわれる。

従つて, 停留辠丸に括いても末梢血中 T. が正常範囲 にあり二次性徵が正常であつても, 自験例の結果から証 明されたごとくに抢そらく鋅丸組織中の T. 濃度低下の ために精子形成能の低下を招いている可能性は十分に存 在し本症の今後の治療方向を示唆するものである.

b ）治療の対象としての反対側陰聂内䁄丸

片側性停留等丸に括いては，その不妊率をみると表 6 (McCollum, 1935) ${ }^{61)}$, (Hansen, 1949) ${ }^{62)}$, (Mai-
表 6 Fertility in Unilateral Cryptorchids Treated by Prepubertal Orchidopexy

\begin{tabular}{l|c|c}
\hline & No. of cases & No. of fertile \\
\hline McCollum (1935) & 54 & 51 \\
\hline Hansen (1949) & 36 & 15 \\
\hline Maitland (1953) & 14 & $11^{*}$ \\
\hline Hand (1955) & 12 & $11^{*}$ \\
\hline Scott (1962) & 3 & 3 \\
\hline Kreibich (1973) & 45 & 16 \\
\hline Madersbacher (1972) & 36 & 9 \\
\hline \multicolumn{1}{c|}{ Total } & 200 & $100(50.0 \%)$ \\
\hline
\end{tabular}

* Fertility based on reported paternity.

tland, 1953) $)^{63)}$, (Hand, 1955) ${ }^{64)},(\text { Scott, 1962) })^{65)}$,

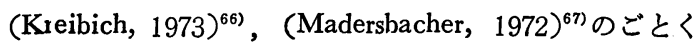
であり思春期前に鋅丸固定術を施行した場合でもその統 計は50\%であり想像以上に低い事実が存在する（表 6 ）.

これらの臨床的事実の他に反対側陰襄内睾丸の変化に 注目した報告がみられる。

和久 ${ }^{14)}$ は，思春期後の 12 例の片側性停留童丸症例につ いてその精液所見は, Normospermie 3 例, Hypospermie 4 例, Azospermie 3 例であり, その反対側陰嘳内辠丸 の組織所見としては disorganization, Sertoli cell only hypospermatogenesis がみられたとしている.

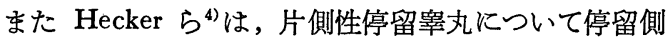

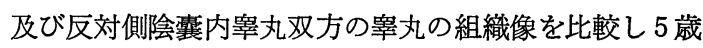
未満では両者の間に差はないが 6 ～10歳では年踰相当の

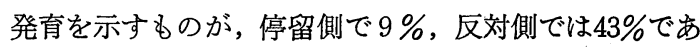
るという.さらに11〜15歳になると反対側陰囊内舎丸で

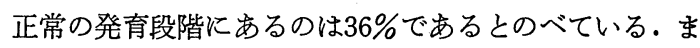
た Atkinson ${ }^{68)}$ (1973) は，guinea pig を使つて片側性

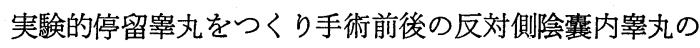
精細管の変化を検討したところ手術前後にその成熟の程 度は全く正常であつたという。さらに Atkinson は, ヒ

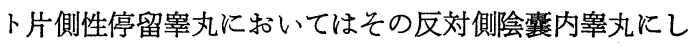
ばしば不完全な発育が認められたことからヒトの場合に は, 片側性停留辠丸症例であつても停留側及び反対側辠 丸共に先天性に異常が存在することを指摘している.

片側性停留拿丸症例の不妊の割合と，これらの事実か

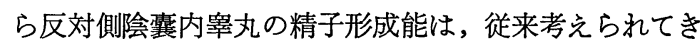
たごとくに全く正常である可能性は否定されるべきであ ると考觉る。 
さらに自験例の結果より反対側陰囊内粹丸に打いても T. 生合成能の 低下が存在している事は前項でのべたご とくその精子形成能の低下とは全く無関係とは思えな い.

本症の治療については従来停留側鼻丸のみを対象にし て手術前後の精子形成能を問題にしてきた。そしてそれ があたかも停留側宰丸のみ精液所見であり妊孕力のごと くに解积されて来た．しかしそれは実は両側圅丸の総合 的結果でありむしろ機能のよいと考兄られる反対側陰褧 内睾丸の精子形成能を主に反映していると考えるべきで あろう。

従つてもし精子減少が存在しているときにはそれは停 留側奝丸のみの責任ではなく，反対側陰囊内䔂丸にも責 を求めるべきである.

また手術（奠丸固定術）を施行したために精液所見に 改善が認められた場合には，手術が反対側陰䨝内蛙丸に 対して手術をしない場合よりも何らかの機序によつて良 い影響を与えた結果と解釈すべきであろう．なぜなら，

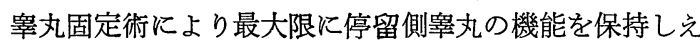

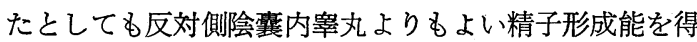
られるとは思劣ないからである。

停留辠丸の発生原因説は，すでに機械的下降障害説よ りも先天異常説が広く認められている。すなわち Schoval ${ }^{69)}$ (1954) は congenital dysgenesis であるとのべ, 昼間23 は辠丸, 副睾丸の附着異常から congenital feminization の一種だとのべている.

これらの事実を前提にして反対側陰慗内臯丸の変化 は何に基因すると考觉るべきであろうか，本来両側共 dysgenesis であり，その変化の軽微であるのが反対側陰 襄内辠丸であるのか，あるいは二次的に停留側睾丸より 何らかの影響を受けて機能低下をしたのが反対側陰製内 辠丸なのであろらか，後者の場合，さらに二次的影響 として hormonal であるのか，あるいは immunological であるのか非常に興味のもたれる点である．Bergada ${ }^{70)}$ (1970)は，一側の辠丸に heat injury を与文たところ， 3 週間後に反対側辠丸精細管に萎縮がみられたと報告し ている. Shirai ら ${ }^{71)}$ (1966) は，実験的に一方の殬丸を

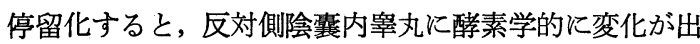
現し停留状態を解除するとその変化が元に復すると報告 している。これらの事実から，二次的な影響も全く否定 する事は出来ない。

この反対側陰囊内睾丸の変化の原因が解明されれば最 初から停留側鼻丸に見切りをつけるか，あるいは反対側
粹丸に悪影響を及ぼさぬように剔除あるいは，固定術な ぞの治療をすればよいかが決定されるであるう。

すなわち，反対側陰豊内辠丸に対する影響を出来るだ け少くする事に努力したうえで反対側陰囊内睾丸に対し 治療を抗こなう事が必要である，要は治療の最終的対象 を従来の停留側等丸そのものから反対側陰囊内辠丸へ向 けようという事である．その上で先にのべたごとく適切 な内分泌治療をも施行されるべきであるうと考える.

\section{結論}

片側性停留辠丸に打ける間質細胞機能をみるため手術 時, 採取した生検組織を用い androgen 生合成能を検索 した。その結果

1. 10歳以下の思春期前の小児蛙丸に打いて steroid 生合成が存在する事が認められた。従来一般に思春期前 に特いては静止状態にあると思われていたが，小児に揖 いても steroid 生合成は active である事を強調した。

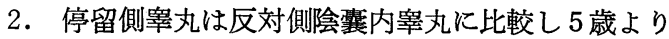
T. 生成率は低下し，その低下は成人に至るまで存在す る.

3. 思春期前の正常小児辠丸との比較では反対側陰襄 内等丸は，正常小児辠丸よりも T. 生成の低下が強く推 測された。

4. 精子形成の主役は androgen である事をのべ，辜 丸組織中の T. 濃度の低下が，本症に打いても不妊の有 力な原因となる可能性をのべた。

5. 反対側陰囊内辠丸の精子形成能は正常ではない事 実をあげ，その間質細胞機能低下とあわせてその変化の 原因によつて本症の治療方針が決まることをのべ，今 後は反対側陰囊内辜丸も治療の対象とすべき事を強調し た。

この論文の要旨は，第 $60 ， 61 ， 63$ 回日本泌尿器科学会 総会, 第12回日本先天異常学会総会, 第10回日本小児外 科学会総会, 第48回日本内分泌学会総会及び第20回日本 不妊学会総会において講演した。

（本文中に打りる steroid の略称）

Prog.: progesterone

$17 \alpha$-OH-P.: $\quad 17 \alpha$-hydroxyprogesterone

$\Delta^{4}$-A'dione: $\quad \Delta^{4}$-androstenedione

T.: testosterone

16 $\alpha$-OH-P: $\quad 16 \alpha$-hydroxyprogesterone

$20 \alpha$-DHP: $\quad 20 \alpha$-dihydroprogesterone

DHT: dihydrotesterone 


\section{文献}

1）公平昭男：日泌尿会誌, 投稿中.

2）昼間 哲：日泌尿会誌，50，679，1959.

3) Cooper, E.R.A.: J. Anat., 64, 5, 1929.

4) Hecker, W.C., Hienz, H.A., Daum, R. and Hollman, G.: Dtsch. Med. Wshr., 92, 786, 1967.

5) Nelson, W.O.: Recent. Progr. Hormone Rec., 6, 29, 1951

6) Robinson, J.N. and Engel, E.T.: J. Urol., 71, 726, 1954.

7) Hinman, F.: Amer. J. Surg., 90, 381, 1955.

8) Sniffen, R.C.: Ann. N. Y. Acad. Sci., 55, 609, 1952.

9) Hand, J.R.: J.A.M.A., 164, 1185, 1957.

10) Schwartz, J.W. and Reed, J.F.: J. Urol., 76, 429, 1956.

11) Wangensteen, O.H.: Arch. Surg., 14, 663, 1927.

12) Rea, C.E.: Arch. Surg., 44, 27, 1942.

13）大田黒和生 : 手術, 22, 1236, 1968.

14）和久正良：日泌尿会誌，48，149，1957.

15) Engel, E.T.: Endocrinology, 16, 513, 1932.

16) Charny, C.W.: J. Urol., 83, 697, 1960.

17) Willkins, L.: The Diagnosis and Treatment of Endocrine Disorder at Childhood and adlescence, p. 566, C.C. Thomas Co., London, 1955.

18) Daniel, D.F.: Abnormal Sexual Development, p. 146, Saunders Co., Philladelphia, London, Toront, 1969.

19) Williams, R.H.: Textbook of Endocrinology, 5th ed., p. 357, W.B. Saunders, Co., Philladelphia, London, Toront, 1974.

20) Nelson, W.O.: Anat. Rec., 54, 30 (Suppl.), 1934.

21) Hanes, F.M. and Hooker, C.W.: Proc. Soc. Exptl. Biol. Med., 35, 549, 1936.

22) Mancini, R.E., Rosemberg, E., Cullen, M., Lavieri, J.C., Vilar, O., Bergada, C. and Ardrada, J.A.: J. Clin. Endocr., 25, 927, 1965.

23) Baillie, A.H. and Mark, W.S.: J. Endocr., 35, 239, 1966.

24）落合京一郎：日泌尿会誌，56，923，1965.

25) Sengoku, K.: Bull. Tokyo. Med. Dent. Univ., 14, 51, 1967.

26) Roland, C.L.: Invest. Urol., 3, 498, 1966.

27) Hadziselmovic, F. and Seguchi, H.: Z. Kinderchir., 12, 376, 1973.

28）近藤猪一郎：日泌尿会誌，53，11，1962.

29) Frasier, S.D.: J. Clin. Endocr., 29, 1404, 1969.
30) Wieland, R.G.: Amer. J. Med. Sci., 259, $358,1970$.

31）丹田 均：日泌尿会誌，62，925，1971.

32) 穂坂正彦, 西村隆一, 長田尚夫, 牧野拓雄 : 木 と臨床，20，583，1972。

33) 穂坂正彦, 西村隆一, 高井修道: 横浜医学, 24, 47, 1973.

34）今野 稔, 穂坂正彦, 西村隆一, 高井修道: 日 泌尿会誌, 65, 637, 1974 .

35) Carlorbe, P. Toublanc, J.E., Job, J.C., Scholler, R., Roger, M. et Castanier, M.: Annales d Endocrinologie (Paris), 35, 177, 1974.

36) Huseby, R.A., Dominguez, O.V. and Samuels, L.T.: Recent Progress in Hormone Rec., 17, 1961.

37) Ono-Imai, K.: The Gumma J. of Med. Sci., 16, 122, 1968.

38) Inano, H. and Tamaoki, B.: Endocrinology, 83, 1074, 1968.

39) Abraham, V.R., Born, H.J., Collischonn, G., Dericks-Tan, J.S.E. und Taubert, H.D.: Endocrinologie, Band 62, Heft 3, 368, 1973.

40）片山 喬：日泌尿会誌, 53, 55, 1962.

41) Hamilton, W. and Grant, J.C.: Acta Endocr. (Kbh) Suppl., 138, 72, 1969.

42）吉田謙一郎, 大島博幸: 日本内分泌学会東部部 会, 1973,2 , 東京.

43）玉置文一：日本内分泌会誌，49，105，1973.

44) Shirai, M., Matsushita, M., Kagayama, M., Ichijo, S. and Takeuchi, M.: Tohoku J. Exp. Med., 90, 363, 1966.

45) Folman, Y.: Endocrinology, 92, 41, 1973.

46）松本圭史, 山田盛男, 安江俊二 : 木子臨床, 20, 1035, 1972.

47) Lee, P.A., Hoffman, W.H., White, J.J., Engel, R.M.E. and Blizzard, R.M.: Am. J. Dis. Child, 127, 530, 1974.

48) Penny, R., Guyda, H.J., Baghdassarian, A., Johanson, A.J. and Blizzard, R.M.: J. Clin. Invest., 49, 1847, 1970.

49) Jenner, M.R., Kelch, R.P., Kaplan, S.L. and Grumbach, M.M.: J. Clin. Endocr., 34, 521, 1972.

50）岩動孝一郎, 福谷恵子, 木下健二, 高安久雄, 松本 泰, 若林克己, 玉置文一: 第20回日本内 分泌学会東部部会総会, 1972.

51) Odell, W.D. and Meyer, L.: Physiology oe Reproduction. p. 95, the Mosby Co., Saint Louis, 1971.

52）穂坂正彦, 西村隆一, 高井修道: 横浜医学, 24, 47, 1973.

53）今野 稔, 穂坂正彦, 西村隆一, 高井修道 : 日 泌尿会誌，65，637，1974. 
54) Maguelone, G.F., Cathiard, A.M. and Bertrand, J.A.: J. Clin. Endocr. Metab., 37, $148,1973$.

55) 穂坂正彦, 今野 稔, 西村隆一, 高井修道: 小 と臨床, 22, 709, 1974.

56) Steinberger, E.: Physiol. Rev., 51, 1, 1971.

57) Morse, H.C.: J. Clin. Endocr. Metab., 37, 882, 1973.

58) Ganjam, V.K. and Amann, R.P.: Acta Endocr., 74, 186, 1973.

59) Hansson, V.: Nature, New Biol., 246, 56, 1973.

60) 穂坂正彦, 西村隆一, 今野 稔, 岩崎 晧, 高 井修道：産婦人科の世界，27，53，1975.

61) McCollum, D.W.: Arch Surg., 31, 290, 1935.

62) Hansen, T.S.: Proc. R. Soc. Med., 42, 645, 1949.

63) Maitland, A.I.L.: Glas. Med. J., 34, 170, 1953.

64) Hand, J.R.: Trans. Amer. Ass. Gen.-Urin. Surg., 47, 9, 1955.

65) Scott, L.S.: Proc. Roy. Soc. Med., 55, 1047, 1962.
66) Kreibich, H. and Kostler, H.: Dtsch. Gesundh,-Wes., 28, 67, 1973.

67) Madersbacher, H., Kövesdi, S. und Frick, J.: Der Urologie, A 11, 210, 1972.

68) Atkinson, P.M.: Brit. J. Surg., 60, 258, 1973.

69) Schoval, A.R.: Am. J. Med., 16, 346, 1954.

70) Bergada, C.: Male Fertility and Sterity, edited by Mancini, R.E. and Martini, L., p. 311, Academic Press, London, New York, Sanfrancisco, 1970.

71) Slaunwhite, W.R. Jr. and Samuels, L.T.: J. Biol. Chem., 220, 341, 1956.

72) Axelrod, L.R.: Biochim. Biophys. Acta., 97, 551, 1965.

73) Liao, S. and Fang, S.: Vitamins and Hormones, 27, 17, 1970.

74) Vida, J.A.: Chemistry and Pharmacology, New York, Academic Press, 1969.

75) Inano, H. and Tamaoki, B.: Endocrinol., 79, 579, 1966.

（1976年 4 月 14 日受付，特別掲載） 